\title{
Saccharomyces boulardii Enhances $N$-Terminal Peptide Hydrolysis in Suckling Rat Small Intestine by Endoluminal Release of a Zinc-Binding Metalloprotease
}

\author{
JEAN-PAUL BUTS, NADINE DE KEYSER, CATHERINE STILMANT, ETIENNE SOKAL, AND \\ SOHEILA MARANDI \\ Laboratory of Pediatric Gastroenterology and Nutrition, Unit of Pediatric Research, Faculty of Medicine, \\ Université Catholique de Louvain, B-1200 Brussels, Belgium
}

\begin{abstract}
Saccharomyces boulardii ( $S$. boulardii), a biotherapeutic agent effective in acute and chronic enterocolopathies, produces trophic intestinal effects at least in part mediated by the endoluminal release of polyamines. However, the effects of the yeast on peptide hydrolysis have not yet been studied. The objectives of this study were to assess in suckling rats the endoluminal and mucosal aminopeptidase activities in response to $S$. boulardii treatment and to analyze their related mechanisms. Peptidase activities were assayed on yeast cells by using several L-amino acid- $p$-nitroanilide substrates in the $\mathrm{pH}$ range of 2 to 10 . A marked hydrolytic activity was found for L-leucine- $p$-nitroanilide that peaked at $\mathrm{pH}=8\left(K_{\mathrm{m}}=0.334 \mathrm{mM}, V_{\max }=44.7\right.$ $\mu \mathrm{mol} \cdot \mathrm{min}^{-1} \cdot \mathrm{g}^{-1}$ protein). $N$-terminal peptide hydrolysis was confirmed using as substrate L-Leu-Gly-Gly $\left(K_{\mathrm{m}}=4.71 \mathrm{mM}, V_{\max }\right.$ $=18.08 \mu \mathrm{mol} \cdot \mathrm{min}^{-1} \cdot \mathrm{g}^{-1}$ protein $)$. Enzyme reactions were inhib-
\end{abstract}

ABSTRACT

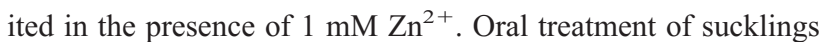
with $S$. boulardii significantly enhanced jejunal and ileal mucosal leucine-aminopeptidase activities by 24 and 34\%, respectively, over controls. In concordance, aminopeptidase activity was enhanced in jejunal and ileal endoluminal fluid samples by 47 and $105 \%$, respectively. By use of an IgG-purified antibody raised against the zinc-binding domain common to metalloproteases, the yeast aminopeptidase was immunoprecipitated and detected as an heteromeric enzyme of 108 and $87-\mathrm{kD}$ subunits. S. boulardii, when given orally to suckling rats, is able to significantly enhance hydrolysis of $N$-terminal oligopeptides in both endoluminal fluid and intestinal mucosa by the endoluminal release of a leucine aminopeptidase that appears to be a zinc-binding metalloprotease belonging to the M1 family of peptidases.

(Pediatr Res 51: 528-534, 2002)
Saccharomyces boulardii (S. boulardii) is a nonpathogenic yeast exerting therapeutic properties in acute and chronic enterocolopathies, antibiotic-associated diarrheas, and enterotoxigenic Clostridium difficile overgrowth (1-4).

In human volunteers $(5,6)$ and in growing rats $(5)$, several studies have documented that oral treatment with a lyophilized preparation of $S$. boulardii produces trophic intestinal effects including increases in the specific and total activities of brushborder membrane (BBM) enzymes (5), enhanced secretion of s-IgA in intestinal fluid (7), and enhanced production of the receptor for polymeric Ig in villus and crypt cells (7). In addition, after oral treatment of rats with $S$. boulardii, there is a marked stimulation of sodium-dependent D-glucose uptake into BBM vesicles with a corresponding accumulation of the BBM sodium D-glucose cotransporter-1 (SGLT-1, 75 kD) (8). These trophic effects are, at least in part, mediated by endolu-

Received February 21, 2001; accepted October 29, 2001.

Correspondence and reprint requests: Jean-Paul Buts, M.D., Ph.D., Department of Pediatrics, Cliniques Universitaires St-Luc, 10 Avenue Hippocrate, B-1200 Brussels, Belgium; e-mail: buts@gype.ucl.ac.be minal release of polyamines, as yeast cells contain substantial amounts of putrescine, spermidine, and spermine $(9,10)$. In addition, polyamine concentrations in mucosa and endoluminal fluid were found to be increased in proportion to the amount of spermine and spermidine supplied by the yeast $(8,9)$.

In neonates and young infants, the quality of endoluminal proteolysis is of great importance, conditioning the absorption of completely or incompletely degraded proteins and antigens by the mucosal barrier whose permeability is increased (11). This is one of the underlying mechanisms inducing food protein intolerance. Likewise, it has been documented that young rats with immature intestinal functions and abnormal mucosal permeability to macromolecules are confronted with more intact food antigens that bind to the enterocyte surface $(12,13)$. In young suckling rats, intact cow's milk proteins are degraded much less than in older rats (13), resulting in increased binding of intact cow's milk antigens to BBM (14).

So far, the effects of $S$. boulardii on intestinal mucosal peptidase activity and endoluminal peptide hydrolysis have not yet been investigated. The objectives of the present study were 
to assess whether oral treatment with lyophilized $S$. boulardii enhances endoluminal and mucosal aminopeptidase activity in suckling rat small intestine and to analyze whether $S$. boulardii produces a protease that after being released into the small intestinal lumen could upgrade hydrolysis of peptides, implying a potential benefit in some situations in which upregulation of intestinal nutrient degradation could be advantageous.

\section{METHODS}

Media and culture conditions. $S$. boulardii cells were inoculated in YPD (yeast extract, $0.5 \%$; peptone, $2 \%$; glucose, $2 \%$; DIFCO, Detroit, MI, U.S.A.) media and grown at $30^{\circ} \mathrm{C}$ with moderate shaking to exponential growth after three replication cycles $\left(5 \times 10^{7}\right.$ cells $\left./ \mathrm{mL}\right)$.

To disrupt the external capsid, yeast cells were concentrated $\left(1.45-1.50 \times 10^{10}\right.$ cells $\left./ \mathrm{mL}\right)$ and shaken with beads $(0.45-\mu \mathrm{m}$ diameter) in six pulses of $30 \mathrm{~s}$ separated by 1 min under cold $\mathrm{CO}_{2}$ flux by using an MSK pulse apparatus (Braun, Paris, France). Viability tests revealed that approximately $100 \%$ of cells were viable with an efficiency of disrupted capsids of $96.7 \%$. After stabilization in $0.1 \mathrm{M}$ phosphate buffer $(\mathrm{pH}=7)$, particulate components were removed by centrifugation $(500$ $\times g$ for $15 \mathrm{~min}$ at $0^{\circ} \mathrm{C}$ ), and the supernatants were stored at $-170^{\circ} \mathrm{C}$ in liquid nitrogen until analyzed.

Animals and treatments. The present study was approved by the Animal Welfare Committee du Fonds de Recherche Scientifique Médicale. Litters of Wistar rats were acclimatized in an air-conditioned room at $21 \pm 1^{\circ} \mathrm{C}$ with a 12 -h light-dark cycle. Immediately after birth, each litter was reduced to six pups per lactating mother to equalize conditions of nursing and feeding. S. boulardii was prepared in a lyophilized form (100 mg per flask, biologic activity $2.9 \times 10^{9}$ viable cells $/ \mathrm{mL}$ ) by the manufacturer (Laboratoires Biocodex, Montrouge, France). As previously reported (5), we used a dose of $0.5 \mathrm{mg}$ of lyophilized yeast cells per gram body weight per day. The appropriate dose was administered in $0.5 \mathrm{~mL}$ saline by nasogastric intubation twice daily from d 11 to 14 postpartum. Control groups were treated according to the same schedule and received equal volumes of saline instead of yeast cells. Six to 10 animals per group were studied. The suckling period was chosen for the experiments because at that time the activity of rat $\mathrm{BBM}$ aminopeptidase is low $(15,16)$ and is mainly located in crypt cells (16).

Preparation of tissues. On d 14 postpartum, rats were killed rapidly by decapitation, and the small intestine from the pylorus to the ileocecal valve was immediately excised. After being rinsed in $0.9 \%$ cold saline, the total length was measured and divided into two equal segments. The proximal half was considered the jejunum and the distal half, the ileum. The mucosa from each segment was scraped off, weighed, and frozen in liquid nitrogen as described (9).

Collection of endoluminal fluid. For the collection of intestinal fluid, jejunal and ileal segments were flushed with $2 \mathrm{~mL}$ of cold $0.9 \%$ saline. The collected fluid was centrifuged $(500 \times$ $g$, $5 \mathrm{~min}$ ), and the supernatants were pooled and filtered through a $0.2-\mu \mathrm{m}$ membrane filter (Millipore) to discard yeast cells in suspension (9).

Enzyme assays. Aminopeptidase activity was assayed on suspensions of $S$. boulardii broken cells, culture media, intestinal mucosa, and intestinal fluid according to Maroux et al. (17) by using several substrates: L-alanine- $p$-nitroanilide, Lleucine- $p$-nitroanilide, L-methionine- $p$-nitroanilide, L-proline$p$-nitroanilide, and L-lysine- $p$-nitroanilide in a 2-aminomethylpropandiol buffer. Unless otherwise indicated, assays were performed at $37^{\circ} \mathrm{C}, \mathrm{pH}=8$, for $30 \mathrm{~min}$. One unit equals 1 $\mu \mathrm{mol}$ of $p$-nitroanilide formed per $\mathrm{min} / \mathrm{g}$ protein. Protein content was determined by the method of Lowry et al. (18).

Peptide hydrolysis. To determine the hydrolytic activity of the yeast enzyme against peptides, $N$-terminal hydrolysis of the tripeptide L-Leu-Gly-Gly $(4.5 \mathrm{mM})$ was assayed in a Tris- $\mathrm{HCl}$ $100-\mathrm{mM}$ buffer $\left(\mathrm{pH}, 8 ; 37^{\circ} \mathrm{C}\right)$ in the presence of broken yeast cell suspensions at two dilutions, $1 / 50$ and 1/500, according to the method published by Vaeth and Henning (19). After an incubation period of $30 \mathrm{~min}$, the assay mixture was centrifuged, and leucine concentration was measured in the deproteinized (sulfosalicylic acid) supernate $(600 \mu \mathrm{L})$. Leucine concentration was determined by an automated amino acid analyzer (Pharmacia LKB, Antwerpen) using the Biochromic 20 software. Results are expressed in micromoles of leucine formed per gram cell protein.

Immunoprecipitation and immunoblotting. To demonstrate the production by $S$. boulardii cells of a metalloprotease, a peptide corresponding to a highly conserved sequence of 36 amino acids was synthesized (Table 1). This sequence includes the zinc-binding domain signature common to all zinc-binding metalloproteases of family M1 (VVQHELAHQW). Rabbits were immunized with peptide AA 298 to 333 corresponding to the sequence of aminopeptidase II from $S$. cerevisiae (Table 1). A polyclonal antiserum was generated, and IgG were purified. One hundred $\mu \mathrm{L}$ of protein $\mathrm{A}$ sepharose- $4 \mathrm{~B}$ beads $(50 \%$ suspension) (Pharmacia, LKB, Antwerpen) was mixed with 1.5 $\mathrm{mL}$ of purified antisera during $4 \mathrm{~h}$ at $4^{\circ} \mathrm{C}$ under gentle continuous rotation. After centrifugation $(500 \times g, 3 \mathrm{~min})$, the supernate was discarded and the beads coated with the antibodies $(100 \lambda)$ were mixed with $1 \mathrm{~mL}$ of $S$. boulardii cell suspension (viable cells, $1.5 \times 10^{10} \mathrm{~mL}$ ), $1 \mathrm{~mL}$ of $0.1 \mathrm{~N}$ $\mathrm{NaOH}$, and $2 \mathrm{~mL}$ of immunoprecipitation buffer containing Tris- $\mathrm{HCl} 100 \mathrm{mM}(\mathrm{pH}=8)$, EDTA $1 \mathrm{mM}$, PMSF $1 \mathrm{mM}$, leupeptin $1 \mu \mathrm{g} / \mathrm{mL}$, and aprotinin $1 \mu \mathrm{g} / \mathrm{mL}$. After overnight incubation at $4^{\circ} \mathrm{C}$, under continuous rotation, the beads were recovered by centrifugation $(500 \times g, 3 \mathrm{~min})$ and washed once with a washing buffer [Tris-HCl $50 \mathrm{mM}(\mathrm{pH}=7.4), \mathrm{NaCl} 100$ $\mathrm{mM}$, SDS $0.1 \%$, Triton-X $100 \%$ ], followed by six washes with the same buffer without $\mathrm{NaCl}$. After aspirating the excess of buffer, immunoprecipitated proteins were solubilized in $30 \mu \mathrm{L}$ of Laemmli's buffer (20) and boiled at $100^{\circ} \mathrm{C}$ for $5 \mathrm{~min}$. Immunoprecipitated proteins were separated by electrophoresis (7.5\% SDS-PAGE) and electrotransferred to polyvinilydene difluoride (PVDF) membranes for $90 \mathrm{~min}$ at $50 \mathrm{~V}$ as described by Towbin et al. (21). Using ${ }^{125}$ I-labeled protein A (Amersham, Ghent), bound antimetalloprotease antibodies were detected by autoradiography using $24 \times 30-\mathrm{cm}$ Fuji film (St. Nicolas, Belgium) at $-70^{\circ} \mathrm{C}$ for 12 to $72 \mathrm{~h}$ (22). 
Table 1. Comparison of identities and zinc-binding domains among human, rat, and $\mathrm{S}$. cerevisiae M1 family of aminopeptidases

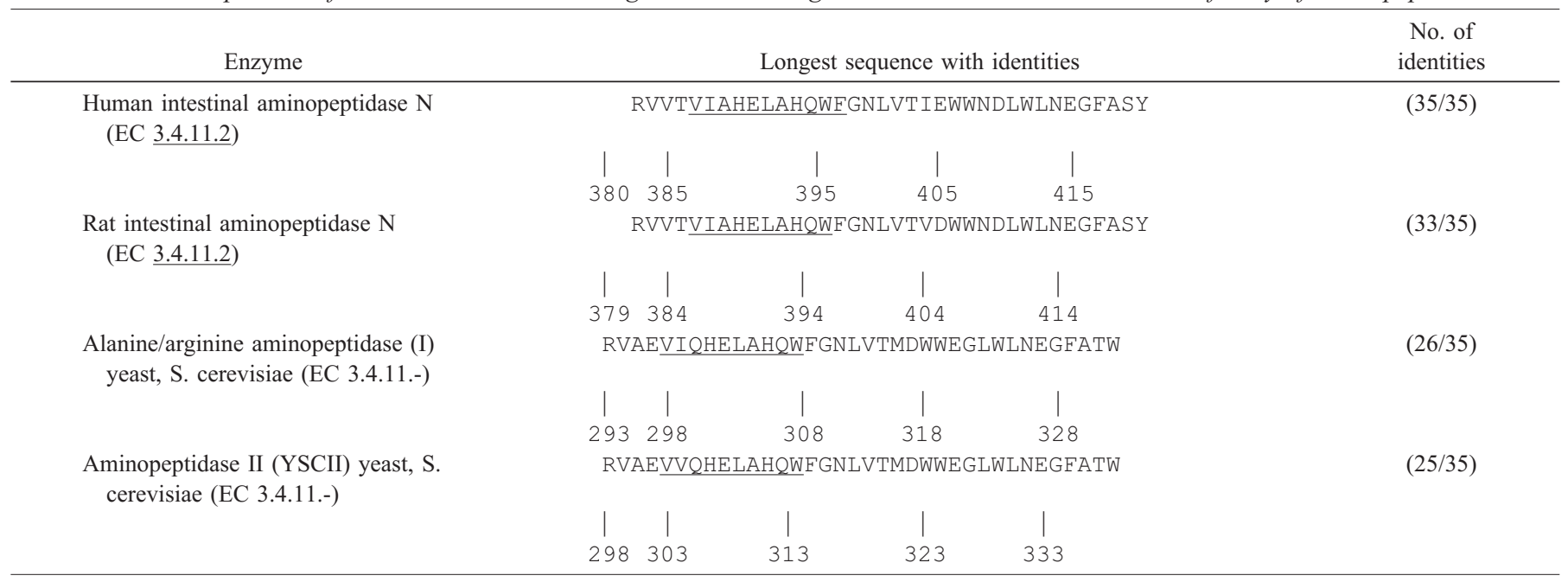

zinc-binding domain signature.

Calculations and statistics. All data are given as mean \pm $\mathrm{SD}$. If not indicated, SD represents less than $5 \%$ of the mean. Differences between controls and $S$. boulardii-treated rats were tested for statistical significance $(p<0.05)$ by using the nonparametric Mann-Whitney $U$ test. $K_{\mathrm{m}}$ and $\mathrm{V}_{\max }$ were calculated using the Prism 3.0 (Graphpad) automated program. Protein band intensities were quantified by densitometry using an image densitometer (CS-690, Bio-Rad). Relative abundance was expressed in arbitrary volume units $\left(\mathrm{OD} \times \mathrm{mm}^{2}\right)$. Relative molecular weights were estimated by densitometry and comparative migration with proteins of known molecular weights.

\section{RESULTS}

Aminopeptidase activity in suspensions of $\mathrm{S}$. boulardii cells and in culture media. Figure 1 represents changes in the specific activity of yeast aminopeptidase measured in $1.5 \times$ $10^{10} / \mathrm{mL}$ viable cells using different substrates (L-alanine, Lleucine-, L-methionine-, L-lysine-, and L-proline- $p$-nitroanilide) at different $\mathrm{pH}(2-10)$ in the incubation media at $37^{\circ} \mathrm{C}$. No activity was detected when L-alanine- $p$-nitroanilide was used as substrate, regardless of the $\mathrm{pH}$ of the incubation medium. L-Methionine- $p$-nitroanilide revealed some activity at low $\mathrm{pH}$ with a peak at $\mathrm{pH} 3$ but very low activities in neutral or basic $\mathrm{pH}$ ranges. L-Lysine- and L-proline- $p$-nitroanilide produced intermediate activities over the whole $\mathrm{pH}$ range, which peaked at $\mathrm{pH}$ 4. L-Leucine- $p$-nitroanilide provided some activity in the acid range, which raised sharply at $\mathrm{pH} 6$ to reach a major peak of activity at $\mathrm{pH} 8$. All these substrates were used at the same concentration $(4.5 \mathrm{mM})$. Addition in excess of $1 \mathrm{mM} \mathrm{ZnCl} 2$ to the medium abolished the reaction (data not shown), demonstrating that the enzyme is a zinc-binding protease. Because L-leucine- $p$-nitroanilide provided the highest activity at $\mathrm{pH} 8$, all subsequent enzyme assays were performed with this substrate. In comparison, human and rat aminopeptidase N, two membrane metalloproteases belonging to the M1 family, are most active at $\mathrm{pH} 8(23)$. Their activities are routinely measured using L-alanine or L-leucine- $p$-nitroanilide substrates, with a $K_{\mathrm{m}}$ of $2.86 \mathrm{mM}$ for L-alanine (24) and $0.647 \mathrm{mM}$ for

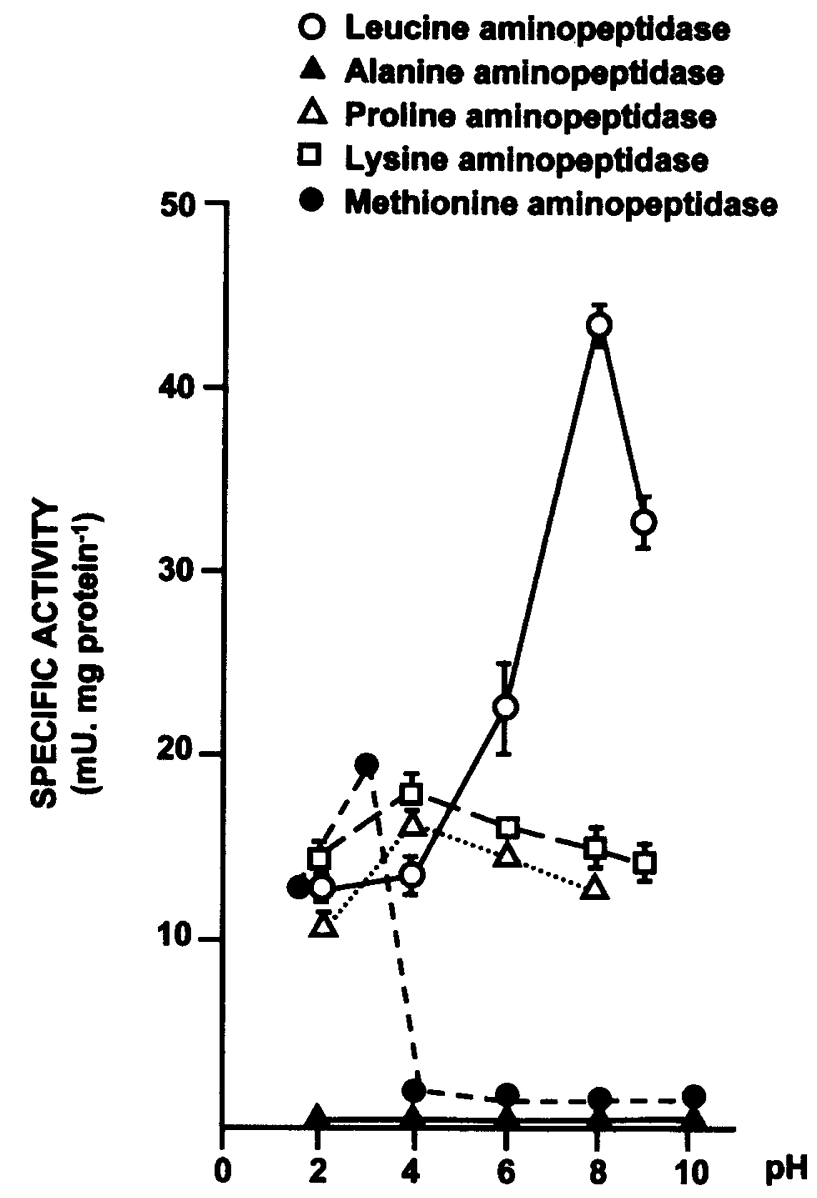

Figure 1. Changes in specific enzyme activities measured in $S$. boulardii cell suspension according to different $N-x$-p-nitroanilide substrates $(4.5 \mathrm{mM})$ at different $\mathrm{pH}$ of the incubation media. Each value represents mean $\pm \mathrm{SD}$ of five individual assays. If not depicted, SD represents less than $5 \%$ of the mean.

L-leucine substrates, respectively (25). Using L-leucine-pnitroanilide as substrate, $K_{\mathrm{m}}$ of the leucine aminopeptidase of $S$. boulardii cells (Fig. 2, left panel) was $0.334 \pm 0.03 \mathrm{mM}$ with a $V_{\max }$ of $44.7 \pm 1.16 \mu \mathrm{mol}$ of $p$-nitroanilide formed per $\mathrm{min} / \mathrm{g}$ cell protein. As shown in Figure 2, the reaction was 


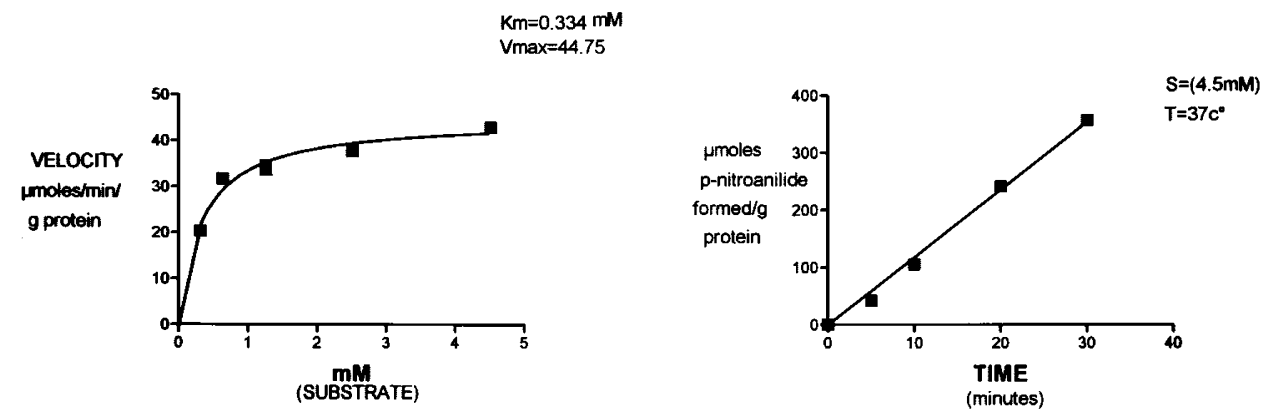

Figure 2. Kinetic parameters of leucine aminopeptidase measured in S. boulardii cell suspension using L-leucine-p-nitroanilide as substrate. (Right panel) Enzyme reaction is linear with time. (Left panel) Velocity according to substrate concentration. Each point represents the mean of three to four individual measurements.

linear with time (right panel) and enzyme concentration (not shown).

Before growth of $S$. boulardii in its appropriate YPG culture medium, no activity of leucine aminopeptidase could be detected (Fig. 3, left panel), whereas after exponential growth, a small amount of enzyme activity was measured into the medium, corresponding to a release of approximately $1 / 5000$ of the total enzyme activity produced by the total mass of yeast cells in culture (Fig. 3, left and central panels). The specific activity of leucine aminopeptidase expressed per gram of yeast cell protein averaged $43 \pm 2 \mathrm{U} / \mathrm{g}$ protein (Fig. 3, central panel).

Peptide hydrolysis. To determine whether the leucine aminopeptidase detected in S. boulardii cells hydrolyses the $\mathrm{N}$ terminal amino acid of oligopeptides, the tripeptide L-Leu-GlyGly was used in vitro as substrate $(4.5 \mathrm{mM})$ in the presence of yeast cells. As shown in Figure 4, the amount of leucine produced per gram of cell protein was linear with time and enzyme concentration (dilutions $1 / 50$ and 1/500). Kinetic analysis at different peptide concentrations revealed a lower affinity of the enzyme for oligopeptides than for nitroanilide derivatives because a $K_{\mathrm{m}}$ of $4.71 \pm 0.47 \mathrm{mM}$ was estimated with a $V_{\max }$ of $18.08 \pm 0.85 \mu \mathrm{mol} \mathrm{L}$-leucine formed per $\mathrm{min} / \mathrm{g}$ cell protein. The same observation was reported for the affinity of rat aminopeptidase $\mathrm{N}$ to L-leucine- $p$-nitroanilide $\left(K_{\mathrm{m}}=0.647\right.$ $\mathrm{mM})(25)$ and L-Ala-Gly $\left(K_{\mathrm{m}}=3.4 \mathrm{mM}\right)(26)$.

Effects of $\mathrm{S}$. boulardii on suckling rat small intestine. There was no difference between treated and control groups regarding initial and final body weight, intestinal length, and jejunal and mucosal weight. Changes in jejunal aminopeptidase activity using L-leucine- $p$-nitroanilide as substrate are shown in Figure 5. Compared with control pups, $S$. boulardii-treated rats exhibited significant $(p<0.01)$ increases in the specific $(24 \%$ versus controls) and total activities of aminopeptidase whether the total activity was expressed per centimeter of gut length (23\% versus controls) or per total jejunum (22\% versus controls). Similarly, the specific and total activities of ileal aminopeptidase were enhanced in S. boulardii-treated rats by 34 and 39\%, respectively, compared with saline-treated controls (Fig. 6). It is noteworthy that the total activity of aminopeptidase measured in $1.5 \times$ $10^{10}$ viable $S$. boulardii cells (Fig. 3, middle panel) was 2-fold higher than the total activity of the enzyme measured in ileal mucosal samples (Fig. 6).

To demonstrate that the increase in jejunal and ileal mucosal aminopeptidase activities was related to the release of a leucine
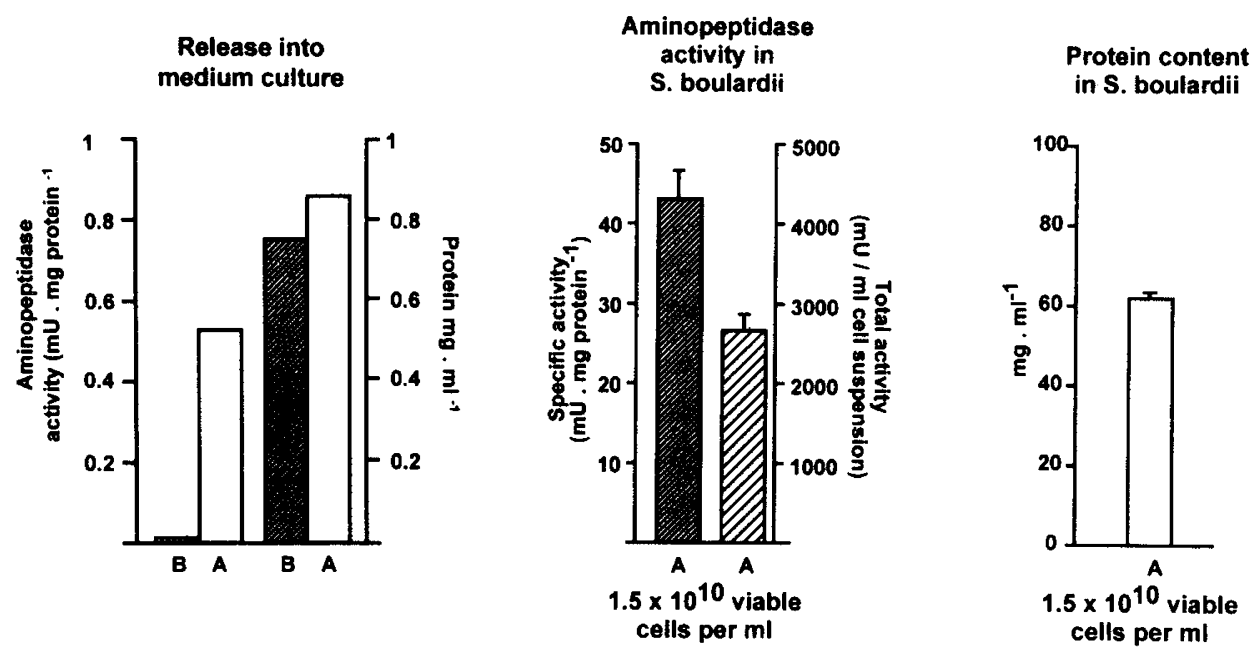

Figure 3. (Left panel) Detection of leucine aminopeptidase activity is figured on the left side and protein concentration in the culture media of $S$. boulardii cells $\left(2 \times 10^{10}\right.$ cells $\left./ \mathrm{mL}\right)$ on the right side before $(B$, stippled bars $)$ and after $(A$, open bars $)$ exponential growth. Values represent mean \pm SD of 10 individual assays. (Center panel) Specific (closed bars) and total (stippled bars) activities of leucine aminopeptidase measured in samples of $S$. boulardii cells $\left(2 \times 10^{10}\right.$ viable cells $/ \mathrm{mL}$ ). Values are mean $\pm \mathrm{SD}$ of 10 individual assays. (Right panel) Protein content of $S$. boulardii cells $\left(2 \times 10^{10}\right.$ viable cells). Values are mean \pm SD of 10 individual assays. 

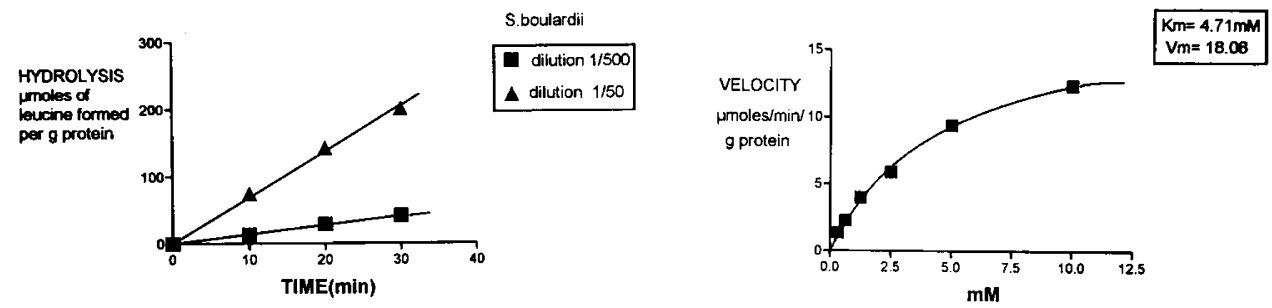

Figure 4. Kinetic parameters of Leu-Gly-Gly peptide hydrolysis measured in S. boulardii cell suspensions using L-Leu-Gly-Gly peptide as substrate. (Left panel) Enzyme reaction is linear with time and enzyme concentration. (Right panel) Velocity according to substrate concentration. Each point represents the mean of three to four individual measurements.

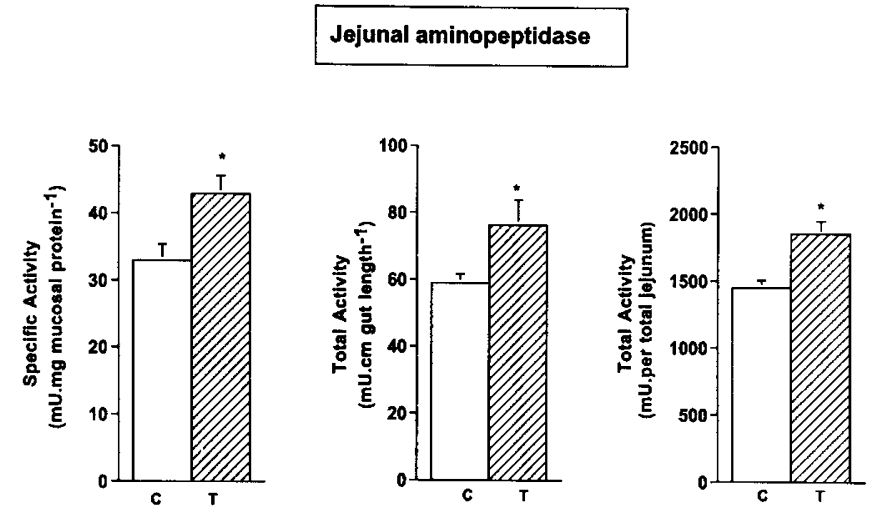

Figure 5. Changes in the specific and total activities of aminopeptidase measured in the jejunal mucosa of suckling pups (d 14 postpartum) treated with a lyophilized preparation of $S$. boulardii $(0.5 \mathrm{mg} / \mathrm{g}$ body weight) or with saline. Each value represents mean $\pm \mathrm{SD}$ of nine individual animals. ${ }^{*} p<$ $0.05 ; * p<0.01$.

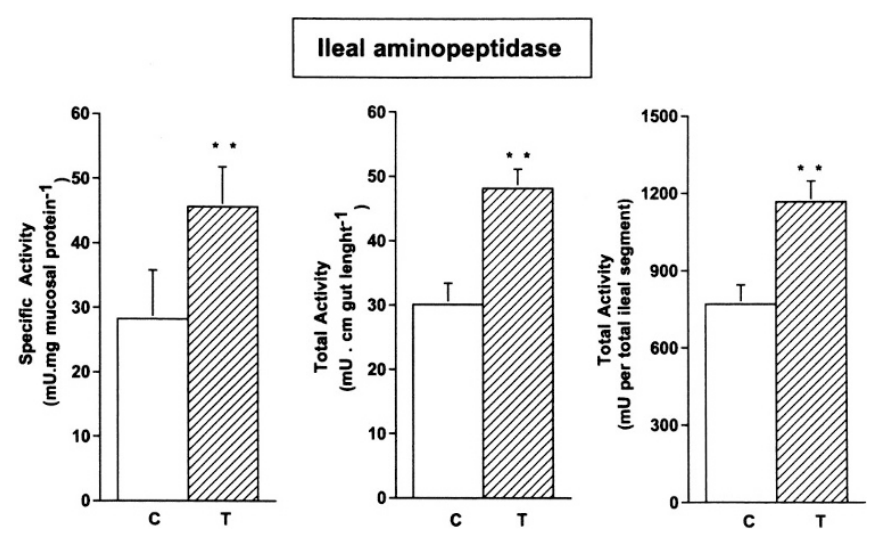

Figure 6. Changes in the specific and total activities of aminopeptidase measured in the ileal mucosa of suckling pups (d 14 postpartum) treated with a lyophilized preparation of $S$. boulardii ( $0.5 \mathrm{mg} / \mathrm{g}$ body weight) or with saline. Each value represents mean $\pm \mathrm{SD}$ of nine individual observations. $* * p<0.01$.

aminopeptidase by yeast cells, the enzyme activity was determined in jejunal and ileal endoluminal fluid samples collected and filtered from sucklings treated with $S$. boulardii or with equivalent volumes of saline. The results are shown in Table 2 . Compared with control rats, leucine aminopeptidase activity was enhanced by $47 \%(p<0.05)$ in the jejunal fluid and by $105 \%(p<0.01)$ in the ileal fluid of $S$. boulardii-treated rats without changes in protein concentration.

Immunoprecipitation of aminopeptidase from $\mathrm{S}$. boulardii. To identify the enzyme of $S$. boulardii cells, we immunoprecipitated the corresponding protein from a pool of yeast cells $\left(1.5 \times 10^{10}\right.$ cells $\left./ \mathrm{mL}\right)$ containing $62 \mathrm{mg}$ protein $/ \mathrm{mL}$ using an IgG-purified polyclonal antibody raised against a sequence of aminopeptidase II from S. cerevisiae (Table 1). The autoradiography shown in Figure 7 demonstrates two single bands of 108 and $87 \mathrm{kD}$, respectively (relative molecular weights). Relative abundance $\left(\mathrm{OD} \times \mathrm{mm}^{2}\right)$ of the $108-\mathrm{kD}$ protein was estimated to be 1.74 and that of the $87-\mathrm{kD}$ protein 11.54 .

\section{DISCUSSION}

Among the major types of proteases, metalloproteases are the most diverse with more than 30 families identified to date (27). Of these, approximately half contain the HEXXH motif, which has been shown to form part of the metal-binding domain (27). Zinc-binding metalloproteases can be grouped together as a superfamily known as the metzincins on the basis of their sequence similarity (27). Family M1 includes bacterial aminopeptidase $\mathrm{N}$ (EC 3.4.11.2), mammalian aminopeptidase $\mathrm{N}$ (EC 3.4.11.2), mammalian glutamyl aminopeptidase (EC 3.4.11.7) or aminopeptidase A, leukotriene A-4 hydrolase (EC 3.3.2.6) (28), alanine/arginine aminopeptidase from S. cerevisiae (gene AAP1) (29), and aminopeptidase II (gene APE2) from $S$. cerevisiae (30). The similarities between the sequences of human, rat, and yeast aminopeptidases that contain the

Table 2. Aminopeptidase activity in jejunal and ileal fluids $(2 \mathrm{~mL})$ collected from suckling rats (d 14) treated with $\mathrm{S}$. boulardii or saline

\begin{tabular}{|c|c|c|c|c|}
\hline & Controls & S. boulardii treated & $\Delta \%^{\mathrm{a}}$ & $\mathrm{P}^{\mathrm{b}}$ \\
\hline No. of rats & 9 & 9 & & \\
\hline Jejunal aminopeptidase (mU/mg protein) & $5.21 \pm 0.47^{\mathrm{c}}$ & $7.69 \pm 1.84$ & +47 & $<0.05$ \\
\hline Protein $(\mathrm{mg} / \mathrm{mL})$ & $1.59 \pm 0.06$ & $1.57 \pm 0.05$ & -2 & $\mathrm{~ns}^{\mathrm{d}}$ \\
\hline Protein $(\mathrm{mg} / \mathrm{mL})$ & $0.93 \pm 0.14$ & $0.92 \pm 0.15$ & -2 & ns \\
\hline
\end{tabular}

\footnotetext{
${ }^{a}$ Variation in percentage of treated group compared with control group.

${ }^{\mathrm{b}}$ Probability $v s$ controls.

${ }^{\mathrm{c}}$ Data are mean $\pm \mathrm{SD}$.

${ }^{\mathrm{d}} \mathrm{ns}=$ not significant.
} 


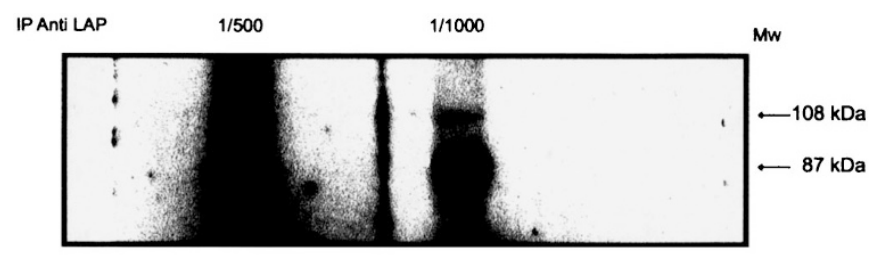

WB Anti LAP

Figure 7. Autoradiography of immunoprecipitated proteins of S. boulardii immunoblotted with a specific antibody recognizing the zinc-binding domain of aminopeptidases of family M1. Note the presence of two subunits at 108 and $87 \mathrm{kD}$ (relative molecular weights), respectively. Abundance of the 108-kD subunit is $1.74\left(\mathrm{OD} \mathrm{U} \times \mathrm{mm}^{3}\right)$, whereas the abundance of the $87-\mathrm{kD}$ subunit is $11.54\left(\mathrm{OD} \mathrm{U} \times \mathrm{mm}^{2}\right)$. Left lane, antibody dilution for Western blot was $1 / 1000$; right lane, antibody dilution was $1 / 500$.

zinc-binding motif are shown in Table 1. Alanine/arginine aminopeptidase and aminopeptidase II from $S$. cerevisiae have been identified by genomic DNA sequencing, but the corresponding proteins have not yet been characterized $(29,30)$.

In the present study, we found that cultured $S$. boulardii expressed a peptidase activity that was highest at neutral or slightly basic $\mathrm{pH}$ for leucine-bound substrates. $K_{\mathrm{m}}$ of the enzyme for L-leucine- $p$-nitroanilide was $0.336 \mathrm{mM}$, which is lower than the $K_{\mathrm{m}}$ of rat aminopeptidase $\mathrm{N}$ for the same substrate $(0.647 \mathrm{mM})$. In addition, the enzymatic reaction was inhibited in the presence of an excess of $\mathrm{Zn}^{2+}$, which suggests that this peptidase belongs to the M1 family of zinc-binding metalloproteases. Aminopeptidase II from S. cerevisiae is believed to be involved in the cellular supply of leucine from externally offered leucine-containing di- or tripeptide substrates (30). We found similar properties of $S$. boulardii peptidase against the peptide L-Leu-Gly-Gly. In vitro, leucine was hydrolyzed proportionally to the amount of enzyme and to the duration of the reaction. $K_{\mathrm{m}}$ of the enzyme for L-Leu-Gly-Gly was $4.71 \pm 0.47 \mathrm{mM}$, indicating a lower affinity for oligopeptides than for nitroanilide derivatives. Similar findings have been published for microvillus aminopeptidase $\mathrm{N}(25,26)$. In a rat model of small bowel resection, Zaouche et al. (31) found that rats treated with $S$. boulardii exhibited an increase in aminopeptidase-N activity, but the reason for this increase remained unknown.

In infants and suckling pups, mucosal aminopeptidase activity is very low and progressively increases during the weaning period to reach peak levels at the end of the first month postpartum $(15,16)$. Compared with age-matched controls, administration to suckling rats of a lyophilized preparation of $S$. boulardii significantly enhanced leucine aminopeptidase activity in both the jejunal and ileal mucosa as well as in endoluminal fluid, implying that the yeast peptidase activity was preserved in lyophilized preparations, resisted gastric acidity and bilipancreatic secretions, and was released in endoluminal fluid, presumably by disruption of the capsid by glycanases produced by the microflora. Figure 1 shows that without capsid, approximately $25 \%$ of the enzyme activity was preserved in the acid range between $\mathrm{pH} 2$ to 4 using L-leucine$p$-nitroanilide as substrate. Concordant findings were published by Pothoulakis et al. (32) who demonstrated that $S$. boulardii secretes in vivo a protease of approximately $54 \mathrm{kD}$ that was resistant to acidity and was able to inhibit binding of purified $\left[{ }^{3} \mathrm{H}\right]$-labeled $C$. difficile enterotoxin A to rabbit ileal BBM by $37 \%$, to reduce enterotoxin-induced fluid secretion by $55 \%$ in rat ileal loops, and to decrease mannitol permeability by $93 \%$ $(32,33)$.

The autoradiography shown in Figure 7 demonstrates that two single bands of 108 and $87 \mathrm{kD}$, respectively (relative molecular weights), were detected. These proteins presumably represent subunits of the yeast aminopeptidase because, in rat and human BBM, aminopeptidase $\mathrm{N}$ is a tetrameric (enzyme I) or dimeric (enzyme II) enzyme with $\alpha$ - and $\beta$-subunits $\left(\alpha_{1} \alpha_{2}\right)$ $(\alpha=91 \mathrm{kD})$ or $\left(\alpha_{1} \beta_{1}\right)(\beta=71 \mathrm{kD})(23)$. The $87-\mathrm{kD}$ subunit was 6.5 -fold more abundant than the $108 \mathrm{kD}$.

Preliminary reports indicate that oral administration of bacterial or yeast biotherapeutic agents to infants may have a preventive effect on the development of chronic persistent or chronic protracted diarrhea after acute gastroenteritis, presumably by intestinal immune reactions against food allergens (3, 34). For instance, Lactobacillus casei strain GG, given orally to children with Crohn's disease, significantly increases the number of cells secreting specific IgA to $\beta$-lactoglobulin and to casein (35). In the case of oral treatment with S. boulardii, several mechanisms may be involved including immunostimulatory effects of the gut-associated-lymphoid tissue (GALT) system with enhanced secretion of specific s-IgA (7), inhibition of toxin binding to enterocyte receptors by proteolysis (32), and endoluminal production of polyamines (9) that decrease intestinal permeability and stimulate BBM enzymes (5) and transporters (8). In the present study, we show that the endoluminal release of an aminopeptidase by $S$. boulardii upgrades endoluminal $N$-terminal hydrolysis of oligopeptides that could be potentially important in preventing reactions to food antigens when mucosal permeability is increased. Further work is warranted to confirm this mechanism in infants and children.

Acknowledgments. The authors thank Bernard Hublot and Paul Bernasconi for helpful advice and Nguyen Van for technical assistance. We also thank Dominique Vermeulen for preparation of the manuscript.

\section{REFERENCES}

1. Surawicz CM, Elmer G, Speelman P, MacFarland LV, Chinn J, Van Belle G 1989 Prevention of antibiotic-associated diarrhea by Saccharomyces boulardii: a prospective study. Gastroenterology 96:981-988

2. MacFarland LV, Surawicz CM, Greenberg RN, Elmer GW, Moyer KR, Melcher SA 1995 Prevention of $\beta$-lactam-associated diarrhea by Saccharomyces boulardii compared with placebo. Am J Gastroenterol 90:439-448

3. Buts JP, Corthier G, Delmée M 1993 Saccharomyces boulardii for Clostridium difficile-associated enterocolopathies in infants. J Pediatr Gastroenterol Nutr 16:419425

4. MacFarland LV, Surawicz CM, Greenberg RN, Fekety R, Elmer GW, Moyer KA 1994 A randomized placebo-controlled trial of Saccharomyces boulardii in combination with standard antibiotics for Clostridium difficile disease. JAMA 271:19131918

5. Buts JP, Bernasconi P, Van Craynest MP, Maldague P, De Meyer R 1986 Response of human and rat small intestinal mucosa to oral administration of Saccharomyces boulardii. Pediatr Res 20:192-196

6. Jahn HU, Ulrich R, Schneider T, Liehr RM, Schieferdecker HM, Holst H, Zeit M 1996 Immunological and trophical effects of Saccharomyces boulardii on the small intestine of healthy human volunteers. Digestion 57:95-104

7. Buts JP, Bernasconi P, Vaerman JP, Dive C 1990 Stimulation of secretory IgA and secretory component of immunoglobulins in small intestine of rats treated with Saccharomyces boulardii. Dig Dis Sci 35:251-256 
8. Buts JP, De Keyser N, Marandi S, Hermans D, Sokal EM, Chae YHE, Lambotte L, Chanteux H, Tulkens PM 1999 Saccharomyces boulardii upgrades cellular adaptation after proximal enterectomy in rats. Gut 45:89-96

9. Buts JP, De Keyser N, De Raedemaeker L 1994 Saccharomyces boulardii enhances rat intestinal enzyme expression by endoluminal release of polyamines. Pediatr Res 36:522-527

10. Miret W, Solari AJ, Barderi PA, Goldenberg SH 1992 Polyamines and cell wall organization in Saccharomyces cerevisiae. Yeast 8:1033-1041

11. Stern M 1991 Gastrointestinal allergy. In: Walker AW, Durie PR, Hamilton RJ, Walker-Smith JA, Watkins JB (eds) Pediatric Gastrointestinal Disease, 1st Ed, Vol I. Philadelphia, Toronto, BC Decker, pp 557-569

12. Stern M, Walker WA 1984 Food proteins and gut mucosal barrier I. Binding and uptake of cow's milk proteins by adult rat jejunum in vitro. Am J Physiol 246:G556-G562

13. Stern M, Pang KY, Walker WA 1984 Food proteins and gut mucosal barrier II. Differential interaction of cow's milk proteins with the mucus coat and the surface membrane of adult and immature rat jejunum. Pediatr Res 18:1252-1256

14. Stern M, Gelleman B 1988 Food proteins and maturation of small intestinal microvillus membranes (MVM) I. Binding characteristics of cow's milk proteins and concanavalin A to MVM from newborn and adult rats. J Pediatr Gastroenterol Nutr 7:115-121

15. Aurichio S, Stellato A, De Vizia B 1981 Development of brush-border peptidases in human and rat small intestine during fetal and neonatal life. Pediatr Res 15:991-995

16. Raul F, Simon P, Kedinger M, Haffen K 1977 Intestinal enzyme activities in isolated villus and crypt cells during postnatal development of the rat. Cell Tissue Res 176:167-178

17. Maroux S, Louvard D, Baratti J 1973 The aminopeptidase from hog intestinal brush border. Biochim Biophys Acta 321:282-295

18. Lowry OH, Rosebrough NJ, Farr AL, Randall RJ 1951 Protein measurements with the folin-phenol reagent. J Biol Chem 193:265-275

19. Vaeth GF, Henning SJ 1982 Postnatal development of peptidase enzymes in rat small intestine. J Pediatr Gastroenterol Nutr 1:111-117

20. Laemmli VK 1970 Changes in structural protein during the assembly of the head of bacteriophage T4. Nature 277:660-685

21. Towbin H, Staehlin J, Gordon J 1979 Electrophoresis transfer of proteins from polyacrylamide gels to nitrocellulose sheets: procedure and some applications. Proc Natl Acad Sci USA 76:4350-4354

22. Buts JP, De Keyser N, Marandi S, Maernoudt AS, Sokal EM, Rahier J, Hermans D 1997 Expression of insulin receptors and of $60-\mathrm{kDa}$ receptor substrate in rat mature and immature enterocytes. Am J Physiol 273:G217-G226
23. Gray GM, Santiago NA 1977 Intestinal surface amino-oligopeptidases: isolation of two weight isomers and their subunits from rat brush border. J Biol Chem 25:49224928

24. Yoshimoto T, Murayama N, Honda T, Tone H, Tsuru D 1988 Cloning and expression of aminopeptidase P gene from Escherichia coli $\mathrm{HB} 101$ and characterization of expressed enzyme. J Biochem Tokyo 104:93-97

25. McClellan JB, Garner CW 1980 Purification and properties of human intestine alanine aminopeptidase. Biochem Biophys Acta 613:160-167

26. Kozak EM, Tate SS 1982 Glutathione-degrading enzymes of microvillus membranes. J Biol Chem 257:6322-6327

27. Rawlings ND, Barrett AJ 1995 Evolutionary families of metallopeptidases. Methods Enzymol 245:183-228

28. Haeggstrom JZ, Wetterholm A, Shapiro R, Vallee BL, Samuelsson B 1990 Leukotriene A4 hydrolase: a zinc metalloenzyme. Biochem Biophys Res Commun 172:965-970

29. Caprioglio DR, Padilla C, Werner-Washburne M 1993 Isolation and characterization of $\mathrm{AAP}_{1}$. A gene encoding an alanine/arginine aminopeptidase in yeast. J Biol Chem 268:14310-14315

30. Garcia-Alvarez N, Cueva R, Suarez-Rendueles P 1991 Molecular cloning of soluble aminopeptidases from Saccharomyces cerevisiae. Sequence analysis of aminopeptidase ysc II, a putative zinc-metallopeptidase. Eur J Biochem 202:993-1002

31. Zaouche A, Loukil C, De-Lageusie P, Peuchmaur H, Macry J, Fitoussi F, Bernasconi P, Bingen E, Cezard JP 2000 Effects of oral Saccharomyces boulardii on bacterial overgrowth, translocation, and intestinal adaptation after small bowel resection in rats. Scan J Gastroenterol 35:160-165

32. Pothoulakis C, Kelly CP, Joshi MA, Gao N, O'Keane CJ, Castagliuolo I 1993 Saccharomyces boulardii inhibits Clostridium difficile toxin A binding and enterotoxicity in rat ileum. Gastroenterology 104:1108-1115

33. Castagliuolo J, LaMont JT, Nikulasson ST, Pothoulakis C 1996 Saccharomyces boulardii protease inhibits Clostridium difficile toxin A: effects in the rat ileum. Infect Immun 64:5225-5232

34. Marteau P, Cellier C 1999 Immunological effects of biotherapeutic agents. In: Elmer GW, McFarland LV, Surawicz Ch (eds) Biotherapeutic Agents and Infectious Diseases. Humana Press, Totowa, New Jersey, pp 121-144

35. Malin M, Suomalainem H, Saxelin M, Isolauri E 1996 Promotion of IgA immune response in patients with Crohn's disease by oral bacteriotherapy with Lactobacillus GG. Ann Nutr Metab 40:137-145 